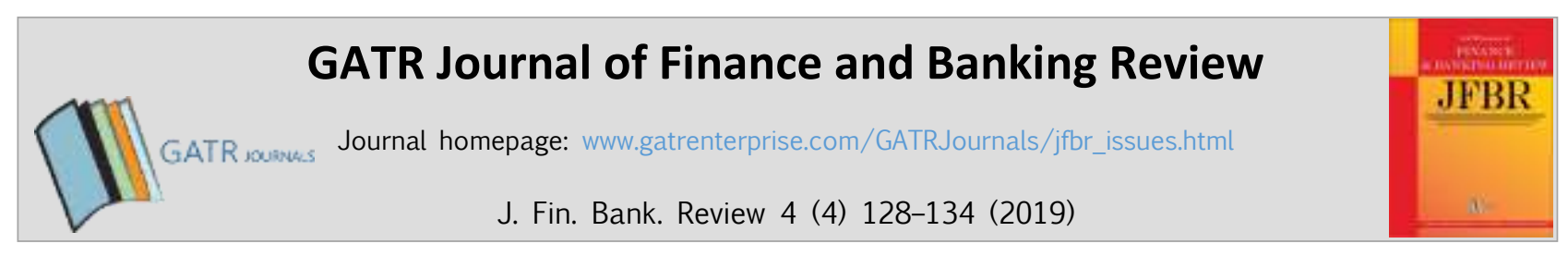

\title{
The Effect of Ownership Structure, Cash Holding and Tax Avoidance on Income Smoothing
}

\author{
Nico Alexander \\ Trisakti School of Management, Kyai tapa No. 20, 11440, Jakarta, Indonesia
}

\begin{abstract}
Objective - This study aims to undertake an empirical study of the influence of ownership structure, cash holding, and tax avoidance on income smoothing.

Methodology/Technique - Ownership structure in this research is measured by public ownership and managerial ownership. The population of this research are manufacturing companies listed on the Indonesian Stock Exchange (IDX) between 2015-2017 and there are 50 companies that meet the criteria and serve as the research sample. The sample selection in this study uses purposive sampling and the hypotheses were tested using binary logistics.

Findings - The results of this study show that managerial ownership and public ownership, cash holding by companies and tax avoidance do not have influence on income smoothing. These results show that managerial ownership and public ownership do not affect income smoothing because there are same interest, to improve their wealth. Similarly, neither how much cash is held by a company nor tax avoidance behavior effect income smoothing.
\end{abstract}

Type of Paper: Empirical

Keywords: Income Smoothing; Ownership Structure; Cash Holding; Tax Avoidance.

Reference to this paper should be made as follows: Nico Alexander. (2019). The Effect of Ownership Structure, Cash Holding and Tax Avoidance on Income Smoothing, J. Fin. Bank. Review, 4 (4): 128 - 134 https://doi.org/10.35609/jfbr.2019.4.4(3)

JEL Classification: G23; G28.

\section{Introduction}

Financial statements are a reflection of the company's condition and contain information needed by stakeholders. According to Sugiarti (2017), financial statements are usually widely used by because profits is the primary factor used to assess a company's performance. Management realizes the importance of this earnings information so that management tends to engage in dysfunctional behaviour, such as income smoothing, to make it appear as though the company is making a profit (Budiasih, 2009).

\footnotetext{
* Paper Info: Revised: September 19, 2019

Accepted: December 31, 2019

* Corresponding author: Nico Alexander

E-mail: alexanderocin@gmail.com

Affiliation: Trisakti School of Management, Kyai tapa No. 20, 11440, Jakarta, Indonesia
} 
According to Sari and Lailatul (2017), income smoothing is a customary action taken by management whereby they produce a report that the level of earnings fluctuations is at a small value and is considered normal for the company in a certain period. Income smoothing can be unfavourable to investors, because investors do not have information about the company's actual financial fluctuations (Ginantra \& Asmara, 2015).

According to Kittiakrastein and Srijunpecth (2013), the degree of income smoothing in ASEAN countries is different after the IFRS and before IFRS. Countries that adopt more IFRS such as Malaysia, Singapore and Philippines have less tendency to do income smoothing compared to countries that adopt less IFRS such as Indonesia, Thailand and Vietnam. This means that companies in Indonesia have a lower earnings quality because management tend to do income smoothing to attract investors. When management have higher ownership in companies, the ownership structure will change from manager which is controlled by shareholders, to one that is controlled by the companies (Carlson \& Bathala, 1997). As managerial ownership increases, there is a corresponding increase in managerial ability to modify the company's revenue through accounting policies (Morck et. al., 1988).

Public ownership may provide an incentive to management to perform income smoothing. This is because the public have an expectation about earnings to make a higher market value and when those expectations are not met, it may have a negative impact on market value (Bauwhede et. al., 2003). Therefore, it can be said that higher public ownership will increase the likelihood that management will engage in income smoothing to meet their expectations on market value. To satisfy the interest of shareholder, managers will conduct income smoothing to reduce tax without violating the legal provision. To obtain minimum tax, managers will do income smoothing (Megarani et. al., 2019).

Research about ownership, cash holding, tax avoidance on income smoothing has given rise to varied and mixed results; this is the primary motivation for this research. The research problem is whether managerial ownership, public ownership, cash holding, and tax avoidance have an effect on income smoothing and the purpose of this research is to obtain empirical results on the effect of managerial ownership, public ownership, cash holding and tax avoidance toward income smoothing. This study provides empirical findings on the effect of ownership structure, cash holding and tax avoidance on income smoothing.

\section{Literature Review}

\subsection{Agency Theory}

One of the things that affects earnings management is the conflicts of interest between principal and agent that arises when each party seeks to maintain the level of prosperity; this is known as agency theory (Azlina, 2010). Jensen and Meckling (1976) define an agency relationship as a contract in which the principal uses the other party, which is said to be an agent, to manage the company by granting authority to make decisions. There will be a lot of rational reasons that lead an agent to not act in accordance with the interests of the principal. Jensen and Meckling (1976) state that the separation between the owners and managers of a company may cause agency problems, such as moral hazard and adverse selection.

Moral hazard is a situation where the agent does not implement the things that have been agreed in the employment contract. While adverse selection is a situation where the principal cannot know whether the decisions made by the manager are really based on information that has been obtained or may occur an omission. Jensen and Meckling (1976) also refer to agency costs which include: monitoring expenses by the principal, bonding expenses by the agent and residual loss. In this research, agency theory explains that the practice of income smoothing is related to conflicts of interest between management and owners caused by each party wanting to increase their individual wealth. 


\subsection{The Effect of Ownership Structure on Income Smoothing}

Managerial ownership is the ownership of company shares by management. The relationship between managerial ownership and income smoothing is when managers have a share in company, it can allow the manager freely to control the company's financial statements. According to Mambraku and Hadiprajitno (2014), Morck et. al. (1988) and Habib and Jiang (2012), managerial ownership can conduct income smoothing, because the management can determine the policies and decision of the accounting methods to do income smoothing, such as revenue recognition. Public ownership is the amount of shares owned by the public that are from outside the company. According to Michelson et. al. (2000) and Putra and Suardana (2016), the greater public ownership, the company decides to implement income smoothing in order to create a slight diversity of profits in order to signify a small risk and public have an expectations about earnings to make a higher market value and when those expectations are not met, it may have a negative impact on market value (Bauwhede et. al., 2003). Based on the above, the following hypothesis is proposed:

H1: Managerial Ownership has a positive effect on the probability of Income Smoothing.

H2: Public Ownership has a positive effect on the probability of Income Smoothing.

\subsection{The Effect of Cash Holding on Income Smoothing}

Cash holding refers to the amount of cash held by the company to invest in tangible assets and to provide to investors (Gill \& Shah, 2012). According to Natalie and Astika (2016) and Mambraku and Hadiprajitno (2014), the relationship between cash holding and income smoothing is that companies that have large free cash flow can experience agency problems, that can make managers more motivated to do income smoothing. Based on the above, the following hypothesis is proposed:

H3: Cash Holding Ownership has a positive effect on Income Smoothing.

\subsection{The Effect of Tax Avoidance on Income Smoothing}

According to Pratiwi and Handayani (2014) and Sari and Lailatul (2017), tax avoidance has a positive effect on income smoothing. The relationship between tax avoidance and income smoothing is because companies wants to pay a minimum tax, so management try to move profits from one year to the next year to achieve the minimum tax payment. When companies pay minimum tax, the shareholder will be satisfied because the portion of earnings that the shareholders receive will be higher. Based on the above, the following hypothesis is proposed:

H4: Tax Avoidance has a positive effect on the probability of Income Smoothing.

\section{Research Methodology}

The population used in this research are all manufacturing companies listed on the Indonesian Stock Exchange from 2015 to 2017. The sample selection technique used in this research is purposive sampling to get the sample which matched with purpose of this research. The sample used in this research are 50 companies. To test the hypotheses, logistic regression is used. The dependent variable in this research is income smoothing, and the independent variables are managerial ownership, public ownership, cash holding and tax avoidance. 


\subsection{Definition Operation}

Income smoothing is measured by an index developed by Eckel (1981), with the following formula:

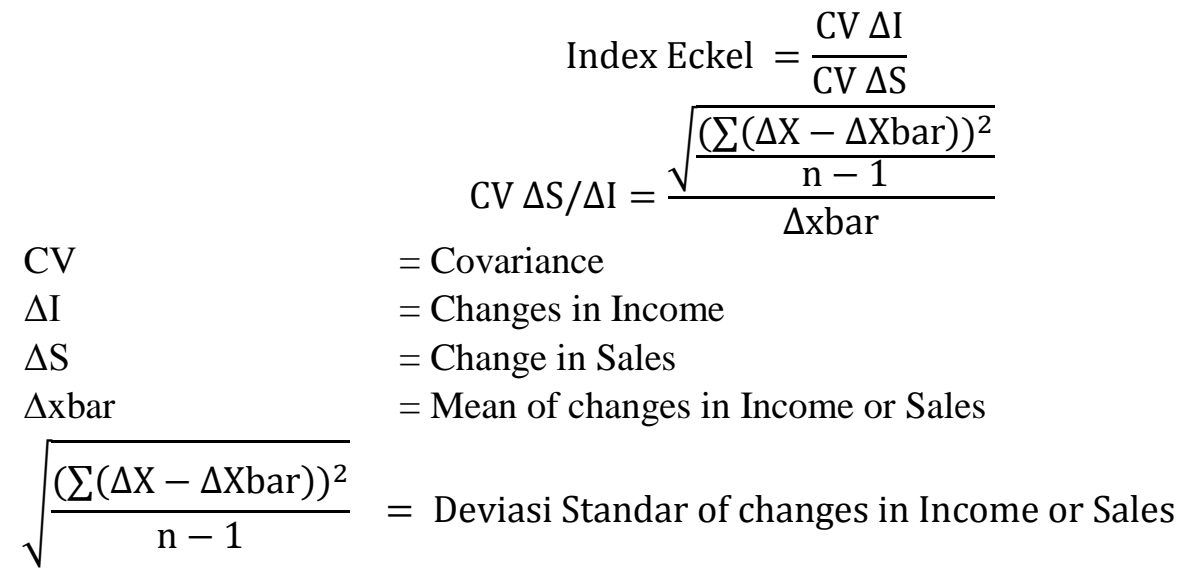

When the index shows less than 1, this indicates that the company does income smoothing and otherwise when the index is more than 1, this indicates that the company does not do income smoothing.

Managerial ownership is the amount of shares owned by the managers, directors and commissioners of the company, with the following formula:

$$
\text { Managerial Ownership }=\frac{\text { Share Owned by Manager, Director and Commissioner }}{\text { Share Outstanding }}
$$

Public ownership is the amount of shares owned by the public that are from outside the company, with the following formula:

$$
\text { Public Ownership }=\frac{\text { Share Owned by Public }}{\text { Share Outstanding }}
$$

Cash holding is measured by the total amount of cash and cash equivalents held by the company divided by its total assets. Tax avoidance is measured by effective tax rate, with the following formula:

$$
\text { Tax Avoidance }=\frac{\text { Current Tax Expense }}{\text { Income Before Tax }}
$$

In this research, the control variable is Firm Size which is measured by a natural logarithm of total assets. Leverage is measured by debt to equity ratio, with the following formula:

$$
\text { Leverage }=\frac{\text { Total Debt }}{\text { Total Equity }}
$$

Profitability is measured by return on assets ratio, with the following formula:

$$
\text { Profitability }=\frac{\text { Net Income }}{\text { Total Asset }}
$$


The research framework of this research is shown below:

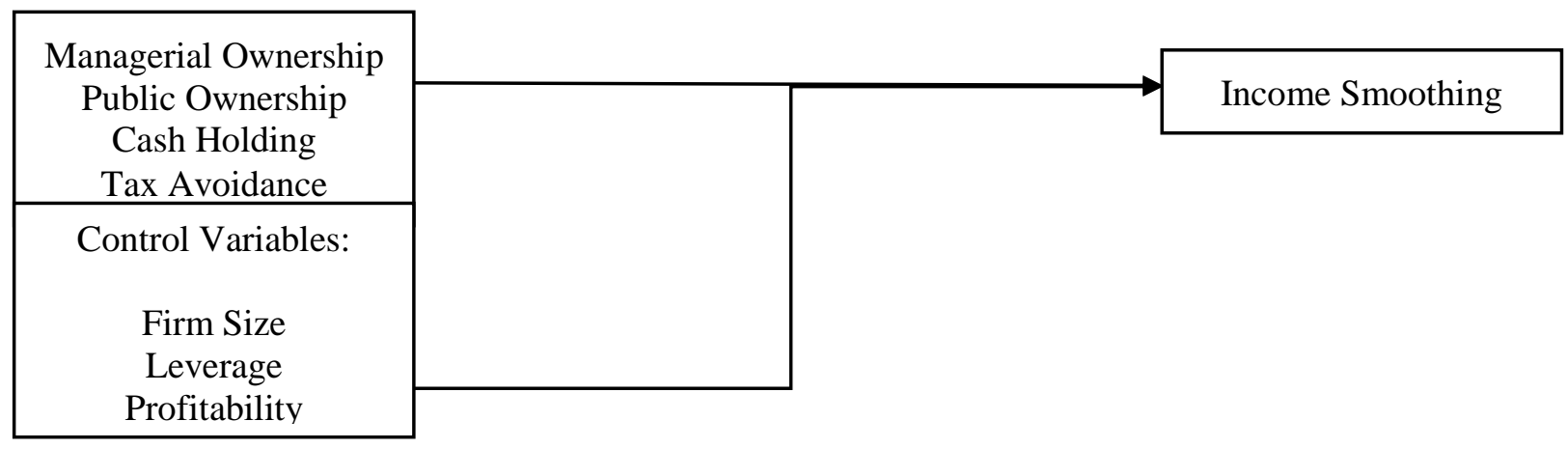

Figure 1. Research Framework

\section{Results}

Table 1 and Table 2 below show the descriptive statistics and hypotheses results.

Table 1. Descriptive Statistic

\begin{tabular}{llllll}
\hline & $\mathrm{N}$ & Minimum & Maximum & Mean & Std. Deviation \\
\hline INCOME & 150 & 0 & 1 & 0,507 & 0,5016 \\
SMOOTHING & & & & & \\
MANAGERIAL & 150 & 0,0000 & 0,3801 & 0,087849 & 0,076058 \\
PUBLIC & 150 & 0,0367 & 0,7060 & 0,285726 & 0,155870 \\
CASH HOLDING & 150 & 0,0021 & 0,6304 & 0,130805 & 0,121779 \\
ETR & 150 & 0,0134 & 0,8599 & 0.277037 & 0,305257 \\
\hline
\end{tabular}

Table 2. Distribution of Income Smoothing

\begin{tabular}{lll}
\hline Variable & Sample & Percentage \\
\hline Not Income & & \\
Smoothing & 74 & $49.3 \%$ \\
Income Smoothing & 76 & $50.7 \%$ \\
\hline
\end{tabular}

From Table 2, it can be said that 74 manufacturing companies from 2015 until 2017 did not perform income smoothing and 76 manufacturing companies from 2015 until 2017 did engage in income smoothing. Most of the companies listed on the Indonesian Stock Exchange do income smoothing in 3 year, from 2015 until 2017. In Indonesia, management, directors, and commissioners have a maximum of $38.01 \%$ ownership in companies, which means they cannot have much ownership in companies. Further, there are a company that have a minimum $3.67 \%$ public ownership in companies. Some companies have a small cash balance, because the cash holding have a minimum value of $0.021 \%$ from its total asset. For tax avoidance, there is some companies that only pay tax equal to $1.34 \%$ of its income. It is a lower tax that has been paid, because in Indonesia, the tax rate is $25 \%$. 
Table 3. Hypotheses Results

\begin{tabular}{lll}
\hline Variable & $\mathrm{B}$ & Sig \\
\hline (Constant) & 2.222 & 0,488 \\
MANAGERIAL & -2.352 & 0.318 \\
PUBLIC & -0.345 & 0.774 \\
CASH HOLDING & -0.941 & 0.559 \\
ETR & 0.449 & 0.592 \\
SIZE & -0.028 & 0.806 \\
LEVERAGE & -0.558 & $0.056^{*}$ \\
PROFITABILITY & -9.327 & $0.005^{*}$ \\
\hline
\end{tabular}

\section{Discussion}

Table 3 shows that managerial ownership, public ownership, cash holding, and tax avoidance do not have an influence on income smoothing. In Indonesia, there only a few companies that allow management to have ownership in the companies, so it is hard to determine the effect of managerial ownership on income smoothing. Many investors have less than 5\% ownership, so they will not affect income smoothing. Additionally, because they are the shareholders, they have a common interest to gain their wealth.

Cash holding in companies does not affect income smoothing because companies need money to operate, so whenever companies need money, management will do income smoothing to attract investor by using income. Tax avoidance does not influence income smoothing. This shows that in higher or lower tax rates, management will do income smoothing to meet investor expectations. Leverage as a control variable has a negative effect on the probability of income smoothing.

This means that companies that have a significant amount of debt will minimize their income smoothing behaviour, because the companies don't need to smooth the income to get debt from creditors. The companies still get debt from creditors even though they have a fluctuating income. Profitability has a negative effect on the probability of income smoothing. This means that companies with higher profitability will minimize income smoothing.

\section{Conclusion}

This purpose of this research is to obtain empirical results on the effect of ownership, cash holding and tax avoidance on income smoothing. The sample used in this research are 150 companies and the results show that of the 4 variables tested, none of the independent variables have influence on income smoothing. The control variables are leverage and profitability. Both control variables have a negative effect on the probability of income smoothing. Public and managerial ownership have a common interest in companies, so they will conduct income smoothing to achieve their own interests. Companies with lower cash holding or higher cash holding will conduct income smoothing to retain their cash and companies do not conduct income smoothing to avoid tax, but to attract shareholders to invest in companies.

As all of the independent variable were found not to have an effect on income smoothing, future research may wish to introduce other measurement variables to determine the effect of those variables on income smoothing, such as institutional ownership, family ownership, controlling ownership, book tax differences and tax savings. Further, future research may use non-financial companies to obtain better empirical results that can be generalized to other research. 


\section{References}

Azlina, N. (2010). Analysis of Factors Affecting Profit Management (Studies in Companies Listed on the IDX). Journal of Economic and Business Education, 2 (03), 8960. https:/www.neliti.com/publications/8960/analisis-faktor-yangmempengaruhi-manajamen-laba-studi-pada-perusahaan-yang-terd

Vander Bauwhede, H., Willekens, M., \& Gaeremynck, A. (2003). Audit firm size, public ownership, and firms' discretionary accruals management. The international journal of accounting, 38(1), 1-22. https://doi.org/10.1016/S00207063(03)00004-9

Budiasih, I. (2009). Factors that influence income smoothing practices. scientific journal of accounting and business. https://ojs.unud.ac.id/index.php/jiab/article/download/2589/1801

Carlson, S. J., \& Bathala, C. T. (1997). Ownership differences and firms' income smoothing behavior. Journal of Business Finance \& Accounting, 24(2), 179-196. https://doi.org/10.1111/1468-5957.00101

Eckel, N. (1981). The income smoothing hypothesis revisited. Abacus, 17(1), 28-40. https://doi.org/10.1111/j.14676281.1981.tb00099.x

Gill, A., \& Shah, C. (2012). Determinants of corporate cash holdings: Evidence from Canada. International journal of economics and finance, 4(1), 70-79. http://dx.doi.org/10.5539/ijef.v4n1p70

Ginantra, I., Gede, K., Putra, I., \& Asmara, N. W. (2015). The Effect of Profitability. Leverage, Company.

Godfrey, J., Hodgson, A., Tarca, A., Hamilton, J., \& Holmes, S. (2010). Accounting theory. https://researchdirect.westernsydney.edu.au/islandora/object/uws:20542/

Habib, A., \& Jiang, H. (2012). Managerial ownership-induced income smoothing and information asymmetry. Pacific Accounting Review. https://doi.org/10.1108/01140581211259839

Kittiakrastein, P., \& Srijunpetch, S. (2013). The accounting quality of the countries in ASEAN after the declaration of AEC establishment. Faculty of Commerce and Accountancy, Thammasat University. http://www.jap.tbs.tu.ac.th/files/Article/Jap25/Full/Jap25PichSil.pdf

Mambraku, Milka Erika dan P. Basuki. 2014. "The Effect of Cash Holding and Managerial Ownership on Income Smoothing (Empirical Study on Manufacturing Companies Listed on Indonesia Stock Exchange 2010-2012)". Diponegoro Journal Of Accounting. Vol. 3, No. 2: 2337-3806.

Michelson, S. E., Jordan-Wagner, J., \& Wootton, C. W. (2000). The relationship between the smoothing of reported income and risk-adjusted returns. Journal of Economics and Finance, 24(2), 141-159. https://doi.org/10.1007/BF02752709

Megarani, N., Warno, W., \& Fauzi, M. (2019). The effect of tax planning, company value, and leverage on income smoothing practices in companies listed on Jakarta Islamic Index. Journal of Islamic Accounting and Finance Research, 1(1), 139-162. http://dx.doi.org/10.21580/jiafr.2019.1.1.3733

Morck, R., Shleifer, A., \& Vishny, R. W. (1988). Management ownership and market valuation: An empirical analysis. Journal of financial economics, 20, 293-315. https://doi.org/10.1016/0304-405X(88)90048-7

Natalie, N., \& Astika, I. B. P. (2016). Effects of Cash Holding, Bonus Plan, Auditor Reputation, Profitability and Leverage on Income Smoothing. E-Journal of Accounting, 943-972.

Pratiwi, H., \& Handayani, B. D. (2014). Effect of profitability, managerial ownership and tax on income smoothing practices. Accounting Analysis Journal, 3 (2). https://doi.org/10.15294/aaj.v3i2.4189

Son, Rizky Anggriawan., Little Brother Suardana. 2016. "The Effect of Variance of Market Price, Public Ownership, and Debt to Equity Ratio on Profit Equity Practices”. University of Udayana E-Journal of Accounting, Vol. 15.3.:21882215.

Sari, Ita Puspita and Lailatul. 2017. "The Factors that Effect Income Smoothing on Manufacturing Companies are listed on the IDX". Journal of Science and Accounting Research, Vol. 6, No. 6

Sugiarti, Rita. 2017. "Factor of Financial Ratio and Good Corporate Governance that effect Income Smoothing". Accountability: Journal of Accounting, Vol.10.2: 247-260. 